\title{
Back into the Imperial Fold: The End of Egyptian Rule through the Court Records of Jerusalem, 1839-1840
}

\author{
Abla Muhtadi and Falestin Naïli
}

The year 1839-1840 often appears as an implicit turning point in chronologies underlying historical research on Palestine and on Jerusalem specifically. It marks the restoration of Ottoman rule over the region after nine years of Egyptian rule and the beginning of the period of Ottoman centralizing reforms in Palestine. The double significance attributed to this year - restoration and reform - translates the ambiguity of the emerging Eastern Question. On the one hand, Britain and her allies actively supported the Ottoman quest to restore rule over Greater Syria, but, on the other, all European countries wished that the door Ibrahim Pasha's rule opened for European influence in Palestine would remain open and that his reforms would endure.

The nine-year period of Egyptian rule has long been presented as a fundamental turning point in the history of Palestine. Many historians have seen the period spanning from 1831 until 1840 as the beginning of modernity in the region, while others see Bonaparte's failed Palestine expedition in 1799 as the start of the modern history of Palestine. Both groups have one conviction in common: modernity sprang from elsewhere. It either hailed from Europe or from Khedival Egypt seen as a voluntary or coerced mediator of European wishes for Palestine.

Reading local sources and looking beyond the usual timeframe are two ways of checking the veracity of this discourse on the onset of modernity in Palestine. There are two important horizons for this inquiry: one is Istanbul and Ottoman aspirations for administrative reforms, and the other is late eighteenth-century Acre and the history of a semiautonomous region, including almost half of what became mandatory Palestine. This chapter examines the court records of Jerusalem, one of the most important local sources for this period. Before we begin to address the records themselves, let us stretch the chronology into the eighteenth century and consider Ottoman imperial politics and Palestinian local leadership.

Although the Ottoman centralizing reforms known as the Tanzimat began with Sultan Abdülmecid's Noble Edict of the Rose Chamber (Hatt-ı Şerîf

(C) ABLA MUHTADI AND FALESTIN NAÏLI, 2018 | DOI:10.1163/9789004375741_013

This is an open access chapter distributed under the terms of the prevailing CC-BY-NC-ND License at the time of publication. 
of Gülhane) in 1839, his father, Mahmud II, had ushered in the reform process during his reign, notably in the army and in provincial administration. The implementation of Mahmud's reforms was only partial in the Arab provinces because the empire was engaged in wars and feared fragmentation. Nonetheless, a change in the system of taxation for instance was announced in Jerusalem just before Ibrahim Pasha's invasion of Palestine. ${ }^{1}$

Palestine was a region of the empire that had at times escaped imperial control. Since the tax-farmer Zahir al-'Umar's rise to local power in northern Palestine in the second half of the eighteenth century, that region, which belonged to the eyālet of Sidon (Saida), saw Acre emerge as a major power center in Greater Syria. While he nominally remained a servant of the provincial governor $(w \bar{a} l \bar{\imath})$ of Sidon, Zahir established semiautonomous rule in the Galilee and sought to expand it as far as Damascus in the north and Gaza in the south. ${ }^{2}$ The governors appointed in Sidon after the Ottomans' victory over Zahir were Ahmad Pasha al-Jazzar, Sulayman Pasha and 'Abdallah Pasha. These governors in many ways built on Zahir's rule and maintained the power and influence of the eyālet of Sidon, which eclipsed that of Damascus, particularly in central and southern Palestine. ${ }^{3}$

In 1826, just five years before Ibrahim Pasha's invasion of Palestine, a tax hike provoked a rebellion of the inhabitants of Jerusalem against the governor of Damascus. The rebellion was quelled by 'Abdallah Pasha, but after achieving his aim, the governor of Sidon reduced the taxes to their previous level and pardoned all the surviving rebels. ${ }^{4}$ In 1830 , the sanjak of Jerusalem came officially under the authority of the eyālet of Sidon alongside the sanjak of Nablus and the sanjak of Acre. All of Palestine was thus governed from Acre. ${ }^{5}$

The context of local challenges to imperial control provides a different framework for analyzing the Egyptian invasion in $183^{1}$ than the one usually employed in historical narratives. On the one hand, it shows how shifts in power on the provincial level - whether spurred by a local tax-farmer turned regional leader or by ambitious long-term Ottoman governors - created new demographic, economic and political realities. On the other, it implies that local political actors in Palestine seized historical opportunities to change the

1 Khaled Safi, The Egyptian Rule in Palestine, 1831-1840: A Critical Reassessment (Berlin: Mensch \& Buch, 2004), 24.

2 Ibid., $15^{-20 .}$

3 Ibid., 20-23.

4 Ibid.

5 Alexander Schölch, "Jerusalem in the 19th Century (1831-1917)," in Jerusalem in History, ed. Kamal J. Asali (Buckhurst Hill: Scorpion, 1989), 23. 
power balance in order to try and make their interests prevail. Concretely, this means that local notables and rural shaykhs chose strategic alliances depending on how they assessed their ally's proneness to satisfy their interests.

Throughout all of the upheavals Jerusalem experienced in the century preceding the Egyptian invasion, some elements of local governance and authority remained stable, namely the role of the judge (qadi) of the Islamic court (mahkama shariyya). The court was a mainstay of imperial power and, though it was a thorn in his side, Ibrahim Pasha could not eliminate it.

A critical reading of the court register (sijill) for the period bridging the end of Egyptian rule and the restoration of Ottoman rule (1839-40) allows us to map the main protagonists of this transition period. It also permits an inquiry into the workings of Ottoman restoration and reform. How did the Ottomans deal with political actors and institutions introduced by the Egyptians on the regional level? In particular, how did they deal with the advisory councils (majlis al-shürā), which had been introduced by Ibrahim Pasha as urban administrative authorities?

In general, the period of Egyptian rule in Palestine remains barely studied but largely charged with significance and ideological interpretations. Future research should take into account the Egyptian administrative archives (which were edited by As'ad Rustum in the 1930s) ${ }^{6}$ as well as the Ottoman State Archives (воА). In addition to local sources, namely the shari'a court registers, and chronicles such as the one written by a Greek monk named Neofytos who describes the period of $1821-41$ in Jerusalem. ${ }^{7}$

\section{Material Aspects of the Source: Entrée en matière}

The sharica court registers (sijillät mahkama shariayya) of Jerusalem represent the oldest and most complete collection of Ottoman court registers in Palestine, covering the period from 1529 to 1917. Microfilms dating from the Ottoman period are accessible in the Islamic Archives in Abu Dis, at the Center for Manuscripts and Documents of the University of Jordan in Amman, in the library of the University of Al-Najah in Nablus and in the library of the University of Haifa. ${ }^{8}$

6 Asad Rustum, The Royal Archives of Egypt and the Origins of the Egyptian Expedition to Syria, 1831-1841 (Beirut: American University of Beirut Press, 1936).

7 S. N. Spyridon, ed., "Annals of Palestine, 1821-1841," The Journal of the Palestine Oriental Society no. 18 (1938).

8 Musa Sroor, “Jerusalem's Islamic Archives," Jerusalem Quarterly, nos. 22/23 (2005). 
The sijill of Jerusalem for $1839-40$, bearing the number 324 , documents the transition from Egyptian to Ottoman rule from the viewpoint of the qadi and the scribe. This 156-page document, written mostly in Arabic, also contains a certain number of Ottoman texts (22 out of 361 judicial documents (hujjaj)) which are mostly copies of sultanic orders (evämir) or decrees (irade) received by the court or official orders given by the judge to other government entities.

This register opens with an introductory text giving the name of the qadi Al-Haj Muhammad Hamdi Effendi - and the name of his deputy and head scribe $(n \bar{a} i b)$ - Muhammad 'Ali al-Khalidi. The imperial order of nomination, dated October 9, 1839, is next in the register. The judge had thus been nominated by the central Ottoman government in Istanbul one year before the restoration of Ottoman rule in Jerusalem in November 1840. Throughout the period of Egyptian rule, the Ottoman central government had continued to nominate the judge of Jerusalem although the territory of jurisdiction was under the control of Ibrahim Pasha by virtue of the Kütahya agreement (1833). ${ }^{9}$

The sijill does not contain any biographical data about the judge himself, but generally, the qadi of Jerusalem was an experienced and high-ranking Ottoman judge from elsewhere in the empire, not from Palestine. This is partly due to the fact that few men from the Arab provinces studied at the Qadis' College in Istanbul..$^{10}$ Due to the religious importance of the city, the qadi of Jerusalem generally "held a higher rank within the Ottoman scholarly hierarchy ('ilmiyye) than did his administrative and military counterparts in the city."11

We learn from the court register that the $n \bar{a} \dot{i} b$, who had been nominated by the qadi, was named Muhammad 'Ali al-Khalidi. ${ }^{12} \mathrm{~A}$ few months after the register records this nomination, another judicial document is devoted to the nomination of the $n \bar{a} i b$ 's son, Yassin, as scribe. The position of $n \bar{a} \dot{ } i b$ and scribe was hereditary in Jerusalem. ${ }^{13}$ Beshara Doumani points out the inherent power of the head scribe: "The bashkätib was empowered to replace the qadi during

9 Safi, The Egyptian Rule in Palestine, 81.

10 Uri Kupferschmidt, "A Note on the Muslim Religious Hierarchy towards the End of the Ottoman Period," in Palestine in the Late Ottoman Period: Political, Social and Economic Transformations, ed. David Kushner (Leiden: Brill, 1986), 124.

11 Gudrun Krämer, A History of Palestine: From the Ottoman Conquest to the Founding of the State of Israel, trans. Graham Harman and Gudrun Krämer (Princeton: Princeton University Press, 2008), $5^{2}$.

12 Jerusalem sijill no. 324, case no. 2, October 9, 1839. He was the father of Yusuf Dhiya' alKhalidi, who would later become mayor of Jerusalem $(1870-76,1878-79)$ and deputy in the Ottoman parliament $(1877-78)$.

13 Jerusalem sijill no. 324, case no. 7, July 1, 1840. 
his absence, sickness, or during transitional periods. In addition, his intimate knowledge of local conditions and connections with other influential members of the community placed him at an advantage vis-à-vis the qadi."14

The register number 324 and the information it contains should therefore be seen in this particular institutional configuration. The court of Jerusalem seems to have been a locus of stability during changing times, with a judge nominated by the Sublime Porte despite Palestine being under Egyptian rule. The $n \bar{a} i b$, the most important officer of the court after the judge, was a member of a local notable family, whose members customarily held the office.

At the same time, this register also has to be considered in the context of the institution that produced it. In many ways, the court and the qadi, along with the mufti, symbolized the essence of the Ottoman legitimating ideology, which was centered on just rule in conformity with the shari'a. ${ }^{15}$ Therefore the court registers cannot be read as simple sources of information, but rather also have to be understood as texts legitimizing Ottoman rule.

\section{The Politics of Administrative Divisions}

As mentioned above, the Ottoman Empire had exercised limited administrative control over Bilad al-Sham prior to the Egyptian occupation of the area in 1831. At the start of the nineteenth century, Greater Syria was divided into four eyālet: eyālet al-Sham (Damascus), eyālet Tarablus (Tripoli), eyālet Saida (Sidon) and eyālet Halab (Aleppo). In 1830, the sanjak of Jerusalem had come under the authority of the eya let of Sidon alongside the sanjaks of Nablus and Acre in a new administrative division that confirmed the preeminence of the governor of Sidon over the governor of Damascus.

With the implementation of Egyptian rule under Ibrahim Pasha, the administrative divisions of Greater Syria were changed again in 1831: eyālet Dimashq al-Sham, eyālet Tarablus and eyālet Saida all came under the authority of the

\footnotetext{
14 Beshara Doumani, "Palestinian Islamic Court Records: A Source for Socioeconomic History," MESA Bulletin 19 (1985): 158.

15 This legitimating ideology can be traced back to the vast mirrors for princes literature, among which the well-known Nasîhat al mulûk (Counsel for kings) by Al Ghazali (1058$1111)$ and Ahlak-i Ala-i by Kinalızade Ali (1511-72). See Hakan T. Karateke and Maurus Reinowski, eds., Legitimizing the Order: The Ottoman Rhetoric of State Power (Leiden: Brill, 2005).
} 
hukm-dâr, the headquarters of Ibrahim Pasha's government, in Damascus. ${ }^{16}$ The eyālet were carved up into mütesellimāt, and the governors heading up each of these subdivisions were nominated by the hukm-dâr in Damascus. ${ }^{17}$ The sanjak of Jerusalem came under the authority of eyālet Dimashq al-Sham and its mutasallim (Ott. Turk. mütesellim) (governor) was nominated by the hukm-dâr. ${ }^{18}$

The Egyptian administrative divisions thus broke up the political continuity officialized by the Ottoman reorganization of 1830 . The latter was a belated official recognition of the influence the eyālet of Sidon had exercised over the Jerusalem area for many decades. When Jerusalem came again under Ottoman rule in November 1840, a letter from the governor (wālī) of Sidon, Muhammad Izzat Pasha, informed the "important personalities" of Jerusalem that the sanjak of Jerusalem was again under the authority of the eyālet of Sidon. ${ }^{19}$

\section{The Main Protagonists of the Transition}

How can we inquire into the political hierarchy in Jerusalem in the period of transition from Egyptian to Ottoman rule? One indication comes from the order in which persons are addressed by official correspondence reproduced in the court register. For example, in a letter sent in December 1840, the Ottoman victory over the Egyptian forces was announced to the following persons enumerated in this order:

1. the hăkim al-shar'i (in other words, the qadi)

2. the mufti

3. the naqïb al-ashrä $f$

4. the mutasallim

5. the descendants of the Prophet (ashräf)

6. the notables or "faces of the town" (wujūh al-balda) in general. ${ }^{20}$

\footnotetext{
16 Abla Muhtadi, Al-Quds, tarikh wa hadara [Jerusalem, history and civilization] (Amman: Dar Majdalawi lil nashr wa'l tawzi', 200o), 364 .

17 Muhammed S. al-Tarawneh, Qada' Jaffa fi al-ahd al-'uthmani [The district of Jaffa during the Ottoman period] (Amman: Ministry of Culture, 2000), 147.

18 Jerusalem sijill no. 321, case no. 4, December 14, 1836.

19 Jerusalem sijill no. 324, case no. 116, p. 43.

$20 \quad$ Ibid., case no. 161, p. 55.
} 
In this document, the preeminence of the qadi is beyond doubt: he was the first person addressed by the imperial government, followed by the mufti and the naqib al-ashräf. On the top level of the political hierarchy we thus have the Ottoman qadi, followed by the local mufti and the local naqïb al-ashräf. These three actors precede the mutasallim in this list, which represents the traditional political hierarchy. It is worthwhile noting that the same order appears in 'Adel Manna's study on the echo of the 1799 French invasion of Palestine in the Islamic court register of Jerusalem. ${ }^{21}$

\section{The Qadi}

The qadi was the highest civil juridical authority in Jerusalem. In theory, he was in charge of all civil and criminal litigation. However, the latter responsibility was limited, since the shari'a includes a relatively small number of offences. In addition to his notarial charge, he had a number of administrative responsibilities linked to religious institutions such as mosques and the many awqā $f$ (pious foundations) properties and institutions.

The qadi clearly played an important role in urban governance during the Ottoman period. This was partly a consequence of his judicial powers, which made him the adjudicator of fiscal conflicts, public security issues caused by conflicts and disputes concerning the distribution of water. 'Arif al-'Arif has pointed out that in addition to the inspection of waqf properties and the control of real estate transactions, the qadi supervised weights and measures and construction permits. ${ }^{22}$

The qadi was generally nominated for one year. Until the mid-nineteenth century, his nomination came in the form of a sultanic decree from Istanbul and was renewable, although in practice, renewals were exceptional. Administratively, he followed the sanjak's affiliation to the eya let, which Jerusalem belonged to at the time. During the Ottoman period in general, the qadi was a trusted representative of the imperial government, which expected him to closely observe the security and political situation in his region of jurisdiction and report back to Istanbul. ${ }^{23}$

21 Adel Manna, "The Sijill as Source for the Study of Palestine During the Ottoman Period, with Special Reference to the French Invasion," in Palestine in the Late Ottoman Period: Political, Social and Economic Transformations, ed. David Kushner (Leiden: Brill, 1986), 357. during the Ottoman Period, ed. Moshe Ma'oz (Jerusalem: Magnes Press, 1975), 337-38. 
When the Ottomans restored their rule in the city in November 1840 , the qadi began to sign the judicial documents (hujjaj) first as "the qadi of Jerusalem and qaimaqam for the governor of Sidon,"24 adding the title of "sirr 'askar hāla (acting army chief)" a few days later. ${ }^{25}$ The qaimaqam was the supreme commander of a region who had civilian as well as military duties. In fact, the qadi had been given full proxy (wakāla mutlaqa) by the wālì of Sidon. ${ }^{26} \mathrm{He}$ transmitted information and gave directions received from the wāli to the mutasallims of Gaza, Ramla, Jaffa and Lod, ${ }^{27}$ as well as to the acting deputy mutasallim of Jerusalem, Ahmad Agha al-Dazdar. ${ }^{28}$ This shows the prominence of his role in the transition from Egyptian to Ottoman rule. He coordinated a number of endeavors, both in the civil and military spheres. For example, the qadi ordered the mutasallims of Gaza, Ramla, Jaffa and Lod to provide for the needs of the Ottoman army which was pursuing the Egyptian army. He also ordered the replacement of some officials linked with the Egyptian administration, such as the treasurers of Jerusalem and Hebron. ${ }^{29}$ Moreover, in an effort to secure the roads in the area, he nominated village shaykhs in the Hebron and Bethlehem area and asked the people to heed their orders. ${ }^{30}$

\section{The Mufti and the naqīb al-ashräf}

The mufti, a religious scholar specializing in the interpretation of Islamic law, was under the authority of the shaykh al-Islam in Istanbul. His juridical advice (fatwa) was an important element in the court's deliberations, and in the absence of attorneys, the mufti's interpretation could function as a plea for one of the parties to a conflict brought before the qadi. ${ }^{31}$ In Jerusalem, this post was held by members of the Husayni family from the end of the eighteenth century onwards. ${ }^{32}$ In 1840, Muhammad Tahir Effendi al-Husayni was the mufti of Jerusalem. ${ }^{33}$

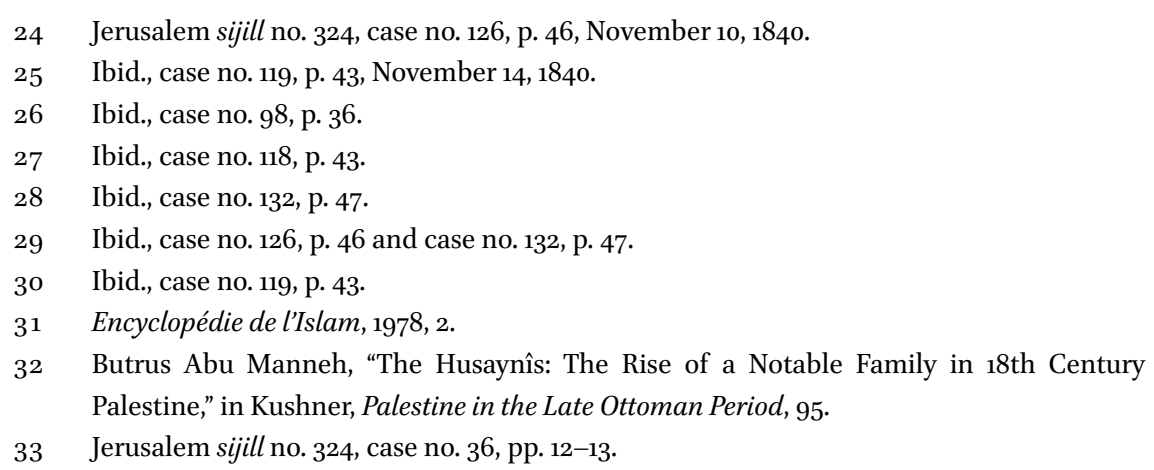


A great amount of moral authority was vested in the figure of the mufti. In 1830, the mufti of Jerusalem, Zahir al-Husayni, signed a fatwa declaring Sultan Mahmud II an infidel, at the request of Muhammad 'Ali. The fatwa, which had been written by the 'ulama' of Al-Azhar, was also signed by the naqïb al-ashrā $f$ of Jerusalem during that period, 'Umar al-Husayni. ${ }^{34}$

The naqïb al-ashrāf was tasked with defending the interests of the descendants of the prophet Muhammad, the ashrāf, even with regards to the qadi. Any legal affair involving a sharif had to be handled in collaboration with the naqīb. In Jerusalem, the naqib was nominated by the qadi after he had been chosen by the notables of the city, including the 'ulama', the ashrā $f$ and other dignitaries. The nomination of the naqib had to be confirmed by the governor and by the chief naqïb al-ashrāf on the imperial level in Istanbul. The "vote" preceding the nomination by the qadi shows that although the naqib nominally only represented the ashrāf, he was a public figure of much greater importance. ${ }^{35}$ As Butrus Abu Manneh has pointed out, the "ashräf were not a closed caste" and there was intermarriage with other families, which meant that ashrā were to be found among all social classes. ${ }^{36}$ In 1840, Muhammad 'Ali al-Husayni was the naqīb al-ashrāf of Jerusalem.

In their article about the Ottoman municipality of Jerusalem, Yasemin Avcr and Vincent Lemire quote a 1844 report from the French consulate in Jerusalem about the role of the naqīb al-ashräf. This report states that the latter had "indirect jurisdiction on the merchants' and workers' corporations" since all of those corporations were headed up by relatively poor ashrāf. Some of them were also simple merchants or craftsmen. Consequently, the naqib was involved in many, if not all, conflicts that emerged in the marketplace. ${ }^{37}$

\section{The mutasallim}

On the list of recipients cited earlier, the mutasallim figures fourth, just before the ashraf and the notables. The mutasallim was the civil governor of a town with very few military tasks, as they were assumed by the qaimaqam. Under

\footnotetext{
34 Safi, The Egyptian Rule in Palestine, 41.

35 Butrus Abu Manneh, "The Husaynîs," 96.

36 Ibid., 97.

37 Yasemin Avcı and Vincent Lemire, "La municipalité ottomane de Jérusalem, 1867-1917," in Municipalités méditerranéennes: Les réformes urbaines ottomanes au miroir d'une histoire comparée (Moyen-Orient, Maghreb, Europe méridionale), ed. Nora Lafi (Berlin: Klaus Schwarz, 2005), 20.
} 
Egyptian rule, the mutasallims of Palestinian cities were generally appointed from among local leaders, who were either from Jerusalem or from nearby towns such as Hebron. Only in 1835-36 do we find a Damascene, Hassan Bey, occupying this function. ${ }^{38}$ It was probably no coincidence that the first governor of Jerusalem after the 1834 rebellion was not from Palestine. During and after the rebellion, four former mutasallims of Jerusalem were killed or executed because of their involvement on the side of the rebels. ${ }^{39}$

The replacement of the mutasallim of the Egyptian government was one of the first decisions after Jerusalem came under Ottoman rule again: on November 6, 1840, a letter from Muhammad Rüstem, the military governor of Damascus, announced that Ahmad Agha al-Dazdar was the interim mutasallim (bi-l-wakäla). It is interesting to note that Ahmad Agha had been the mutasallim of Jerusalem until June 23, 1840, when the Egyptian hukm-dâr of Damascus decided to replace him with Husayn Rashid Effendi. ${ }^{40}$ Although Ahmad Agha had served in the Egyptian administration, he was considered the right person for the interim period. This is an indication of the Ottoman approach to this period of transition, which was characterized by a preference for continuity whenever possible, and also a sign that the Egyptians had probably been right in doubting Ahmad Agha's loyalty to the Khedive. ${ }^{41}$

It is not clear if the Ottomans had a particular policy, before and immediately after the period of Egyptian rule, on nominating a mutasallim who was not from the city in which he exercised his function. However, once the position of mutasallim was changed into mutessarif in 1843 , this official was always from elsewhere. ${ }^{42}$

\section{The majlis al-shürā}

The majlis al-shürā was the major new element in the local governance system established by the Egyptian authorities. This advisory council was under the authority of the Diwān al-shürā in Damascus, which reported to Ibrahim

\footnotetext{
38 Safi, The Egyptian Rule in Palestine, 68.

39 Ibid., 343 .

$40 \quad$ Jerusalem sijill no. 324, case no. 3, p. 2.

41 Safi, The Egyptian Rule in Palestine, 255.

42 Ziyad Al-Madani, Madinat al-Quds wa-juwarha fì awakhir al-'ahad al-'uthmani, 1246/18311336/1918 [The city of Jerusalem and its surroundings at the end of the Ottoman period, 1246/1831-1336/1918] (Amman, 2004), 26-28.
} 
Pasha and was overseen by Muhammad 'Ali himself. ${ }^{43}$ These advisory councils were established in all towns of more than two thousand inhabitants. ${ }^{44}$ Their role was to coordinate the Khedival administrative policies and collect tax revenues. They also had a judicial function as well as an important role in urban governance. ${ }^{45}$ The majlis al-shürā were in charge of fixing price levels, auctioning public charges such as customs, supervising army supplies and mediating complaints from the town's population. ${ }^{46}$ As such, it was a precursor of the municipality. ${ }^{47}$

Khaled Safi has pointed out that Muhammad 'Ali and Ibrahim Pasha had two important political goals in creating the majlis al-shürā: first, they wished to curtail the power of the 'ulama' and the Islamic court, and, second, to confine the shari'a to personal status issues. Muhammad 'Ali could not count on an alliance with the 'ulama' since they were traditionally loyal to the sultan, so he had to empower other segments of local society in an effort to balance out the 'ulama"s influence. While the latter were also members of the majlis al-shürā, the other members of the council owed their new status to Muhammad 'Ali's policies and were thus prone to remain loyal to him. The councils counted between twelve and twenty-two members, ${ }^{48}$ many of whom were urban notables and merchants whose economic and political power increased through their membership of the advisory council and reached new heights after the 1834 revolt and the subsequent weakening of the rural shaykhs..$^{49}$

When Ottoman rule was restored in Jerusalem, the first official correspondence to be sent by the qadi was destined for the majlis al-shürā. He reassured the members of the council that it was going to be maintained as an institution and confirmed the council president in his function. The council president was the head of the teachers ('umdat al-mu'alimin) of Jerusalem, Al-Shaykh Muhammad Effendi Abu al-Sa'ud. The qadi also announced that the membership of the council would be increased by two Muslims, Shakir al-Muwaqat and Nijim al-Din al-Jamai. The confessional composition of the council was thus as follows: eleven Muslims, two Christians and one Jew. The qadi asked

43 Judith Mendelsohn Rood, Sacred Law in the Holy City: The Khedival Challenge to the Otttomans as seen from Jerusalem, 1829-1841 (Leiden: Brill, 2004), 98.

Safi, The Egyptian Rule in Palestine, 84.

45 Mendelsohn Rood, 2002 101; Muhtadi, Al-Quds tarikh wa hadara, 364.

46 Safi, The Egyptian Rule in Palestine, 85.

47 Avcı and Lemire, "La municipalité," 90.

48 Ibid., $83-84$.

49 Ibid., 87-88. 
the council to forward summaries of all affairs to him so that he could elucidate them. ${ }^{50}$

Interestingly, the mutasallim is not mentioned in this letter. During the last months of Egyptian rule, the qadi, in a similar letter to the council, had requested that the affairs also be sent to the mutasallim "for information." ${ }^{51}$ It seems that during the period of transition, the mutasallim played a less important role compared to the qadi and the majlis al-shürā.

In the letter the qadi sent in December 1840, the members of the council are enumerated in what must be their relative importance:

1. The president of the council, Muhammad Effendi Abu al-Sa'ud

2. The naqīb al-ashräf, Muhammad 'Ali al-Husayni

3. Khalil Effendi al-Khalidi

4. 'Uthman Effendi Abu al-Sa'ud

5. Muhammad Darwish 'Ali Effendi Zada

6. Shakir al-Muwaqat

7. Nijim al-Din al-Jamaci

8. Ibrahim al-Muhtadi

9. Muhammad al-Suradi

10. Jarallah, the council's scribe

11. Wafa, the council's assistant scribe

12. Khawāja Runsio, representative of the Jewish community

13. Yusuf (?), representative of the Franji community

14. Yaqub Khan Ahad, representative of the Armenian community. ${ }^{52}$

The first element, which should be noted, is the position of the naqib al-ashräf: second after the council's president. Khalil Effendi al-Khalidi and 'Uthman Effendi Abu al-Sa'ud, the following two people on the list, have not yet been identified apart from their being from notable Jerusalem families. Fifth on the list, Muhammad Darwish Ali Effendi Zada was the representative of the Imaret soup kitchen, a major public charity and waqf institution founded by Hasseki Sultan. ${ }^{53}$ Nijim al-Din al-Jamai, seventh on the list, was the head preacher of Jerusalem. ${ }^{54}$

\footnotetext{
5o Jerusalem sijill no. 324, case no. 122, p. 44, December 9, 1840.

51 Ibid., case no. 11, p. 4.

$5^{2}$ Jerusalem sijill no. 324, case no. 122, p. 44, December 9, 1840.

53 Ibid., case no. 123, p. 44.

54 Ibid., case no. 133, p. 47.
} 
It is also important to consider the representatives of Christian communities. The presence of a Franji - Latin - and Armenian representative on the council and the absence of a representative of the Greek Orthodox (Rūmī) community is striking, given the demographic realities in Jerusalem. The preference for Latins over Greek Orthodox may have been the result of Egyptian efforts to please the European powers. It would be interesting to see how this evolved in the following few years as the Ottomans adapted the majlis al-shūrā to their way of governing.

In the letter, the qadi asked the council members to do their work diligently and to transmit summaries of all issues brought before them to him. ${ }^{55}$ In which capacity did he address the council: as qadi or as qaimaqam? A comparison with the sijill for 1837 reveals that the qadi was not involved in the workings of the majlis al-shūrā at all during that period, so the situation in 1840 was exceptional and probably due to his concomitant status of qaimaqam.

It has been argued that the majlis al-shūrā prefigured the role of district council (majlis idārat al-liwä'), which was introduced later on. ${ }^{56}$ This is true in terms of the composition of the council and its status within the larger political hierarchy. However, in terms of responsibilities, the majlis al-shūrā actually played a role similar to that of the municipality (majlis baladi; baladiyya), which was founded in Jerusalem in the 186os. As mentioned earlier, the majlis al-shürā attributed public charges after auctions, fixed prices, supervised army supplies and received and mediated complaints from the population. We can therefore contend that between 1831 and 1867 , the majlis al-shürā, the naqīb $a l-a s h r a \bar{f}$ and, to a lesser degree, the qadi formed the basis of premunicipal urban governance in Jerusalem.

\section{Conclusion}

In the sijill for 1839-40, we thus have new elements to understand the transition from Egyptian back to Ottoman rule and how this affected urban governance in Jerusalem. The Ottomans relied primarily on the qadi, who had been nominated by Istanbul, and on the mufti and the naqïb al-ashrāf, who were two local notables nominated by the qadi. The mutasallim, who had during some time

55 Ibid., case no. 122, p. 44, December 9, 1940.

56 Shimon Shamir, "Egyptian Rule (1832-1840) and the Beginning of the Modern Period in the History of Palestine," in Egypt and Palestine: A Millennium of Association, 868-1948, ed. Amnon Cohen and Gabriel Baer (Jerusalem: Ben-Zvi Institute for the Study of Jewish Communities in the East, 1984), 221. 
been presented as an almost omnipotent tyrant ruling the area, is relatively less important during the very sensitive period of transition from Egyptian to Ottoman rule.

The analysis of the two letters reproduced in the sijill - the first announcing the Ottoman victory in December 1840, and the second addressed by the qadi to the majlis al-shüra - reveals that the Ottomans pursued a double strategy. On the one hand, they reaffirmed the traditional sociopolitical hierarchy by according much importance to the ashrä $f$ and the notables, as we can see in the list of recipients of the first letter. On the other hand, they actively integrated the majlis al-shürā into the structures of urban governance. Instead of abolishing this advisory council, they subordinated it to the qadi and increased the number of Muslims in it, as evidenced in the second letter. The fact that the Ottomans maintained the majlis al-shūrā should not just be seen as simple Ottoman compliance with European wishes, but should also be considered as coherent with the Ottoman drive for reform as part of the Tanzimat and also as part of the reform ambitions predating the latter. 